\title{
PRESENT STATUS OF NESTING HABITAT OF GREEN TURTLE (Chelonia mydas) IN WEST JAVA-INDONESIA
}

\author{
Adriani Sri Nastiti Krismono"), Amula Nurfiarini"), \\ Ahmad Fitrianto"), and Ngurah Nyoman Wiadnyana ${ }^{2)}$ \\ "Researcher at Research Institute for Fish Stock Enhancement, Jatiluhur-Purwakarta \\ 2) Researcher at Research Centre for Capture Fisheries, Ancol-Jakarta \\ Received May 22-2009; Received in revised form August 28-2009; Accepted November 20-2009
}

\begin{abstract}
The coastal habitat condition much influences the moving of sea turtles to coast for nesting. In West Java Province there are some potential coasts as nesting habitat of sea turtles, but it has experiencing of many damage and has not been touched yet as the protected area for sea turtle nesting habitat. Related to the assessment of nesting habitat condition, the research aims to describe the present status of nesting habitat of green turtle (Chelonia mydas) along the coast of southern part of West Java. The research was conducted during periods of May, June, July, and August 2008, covering the coasts of Sukabumi District (Citireum and Pangumbahan), Cianjur District (Sindang Barang and Cidaun), Tasikmalaya District (Cipatujah), and Ciamis District (Legok Jawa). Observation on green furtle biology and habitat insitu, and interviewing to the local people and the officers working as turtle watcher were conducted. Results indicate that some coasts of West Java Province have potential nesting habitat not only for green turtle, but also for other turtle species. The most recognized area is Pangumbahan coast, Sukabumi District. Other potential coasts for nesting habitat of sea turties are located in Tasikmalaya and Ciamis Regency. Unfortunately, these potential nesting habitats have not been established as area of turtle conservation. It is suggested that the coastal region of West Java should be declared and developed as turtle conservationi arrea according to the national regulation with involving the local people participation.
\end{abstract}

KEYWORDS: $\quad$ green turtle, nesting habitat, conservation, south coast of West Java-Indonesia

\section{INTRODUCTION}

The nesting habitat condition is one of important factors that may influence the success of the life cycle of sea turtles (Nuitja, 1992; Dermawan, 1997; Yusuf, 2000; Dharmadi \& Wiadnyana, 2008). The adult female sea turtles must go up to the beach to lay their eggs. They have to find appropriate nesting habitat condition such as: evaporable humidity, free of predators, many plantations, evaporable quality of sand, smooth elevation of the beach, and free light perturbation (dark condition) (Nuitja, 1992) as well as the beach accessible with deep, loose sand that are above high tide (Miller, 1997). From about 95,181 km coastline of Indonesia, many beaches have those natural conditions and potential as nesting habitat. Some beaches of West Java are determined to be potential as nesting habitat, especially for green turtle (Chelonia mydas). One of known nesting habitats of green turtle is Pangumbahan beach in Sukabumi District. The other places determined are the beaches of Ciamis District, Tasikmalaya District, and Cianjur District.

Green turtle spreads widely in the sea and is categorized as highly migratory species, reaching thousand long distance. Sea turtle migration may be related to the reproduction phase, called "breeding migration", while the migration related to individual growth, called "development migration". The most spesific ability of sea turtle is to be capable to come back home where they are born, this is called "Homing Orientation". Briefly, green turtle migrates for thousand kilometers to get food, forward to around sallow waters to spawning, go up to the beach to nest, and come back to the sea to waiting for internesting and go to foraging ground until next nesting season (Miller. 1997).

From life cycle description, sea turtles need a long periode from begining until reproductive adult for maintaining their population. However, the current condition shows that sea turtle populations are declined (Adnyana et al., 2008). This problem may be mostly due to exploitation of sea turtle by human for many purposes such as food and ornament. Nursahid (2003) stated that sea turties in indonesia are vurnerable and continue to decrease till $50 \%$ per year. At present, sea turtles populations of Indonesia are estimated about 10-20\%. Even though, Indonesia serves as important habitat for allmost sea turtles existing in the world (Dermawan, 1997). In regard to the importance of nesting habitat management, the assessment of nesting habitat is necessary to be conducted. Based on data and information analyzed, the current study would bring a policy concept in habitat conservation management that will be usefull 
for the government authority in decision making process for sea turtle conservation in West Java, as well as Indonesia.

The study describes the current condition of nesting habitat of green turtle in Pangumbahan Beach in comparation with nesting habitat condition of some beaches observed in West Java, and indentifies the participative role of community in sea turtle management.

\section{MATERIALS AND METHODS}

Data and information of ecology of the beach, substrate composition, biology of sea turtle and socioeconomic aspects was collected montly during the peak of nesting season from May-August 2008 at eight nesting beaches (Figure 1), from Banten Province (Karang Ranjang Beach belonging to Ujung Kulon National Park), Sukabumi District (Citireum and Pangumbahan Beaches), Cianjur District (Cidaun and Sindang Barang Beaches), Tasikmalaya District (Cipatujah Beach), and Ciamis District (Legok Jawa and Bulak Benda District). A number of ecological, biological, and socio-economic parameters were observed with spesific methodology listed in Table 1.

\section{RESULTS AND DISCUSSIONS}

\section{Ecology of the Beach}

Eight nesting areas of sea turtles were observed in West Java Province. Its characteristic was compared in detail as outlined in Table 2. In general, the beaches seem be approriate for sea turtle nesting habitat, especially for green turtle (Abdullah \& Ismail, 2004; Yasuda et al., 2005; Dharmadi \& Wiadnyana, 2006). However, Pangumbahan beach is found to be the best nesting habitat for green turtle in West Java region. This good conditon is in correlation with the good beach plantation occured in the long of the beach. The comparison in vegetation condition is outlined in Table 3.

\section{Biological Aspects of Sea Turtles}

\section{Size, number, and nesting activity of green turtle nesters}

From a number of 40 individuals measured at four nesting sites, the curve carapace length (CCL) of green turtle nesters ranged from $89-115 \mathrm{~cm}$. The range of size was relatively longer than that reported previously

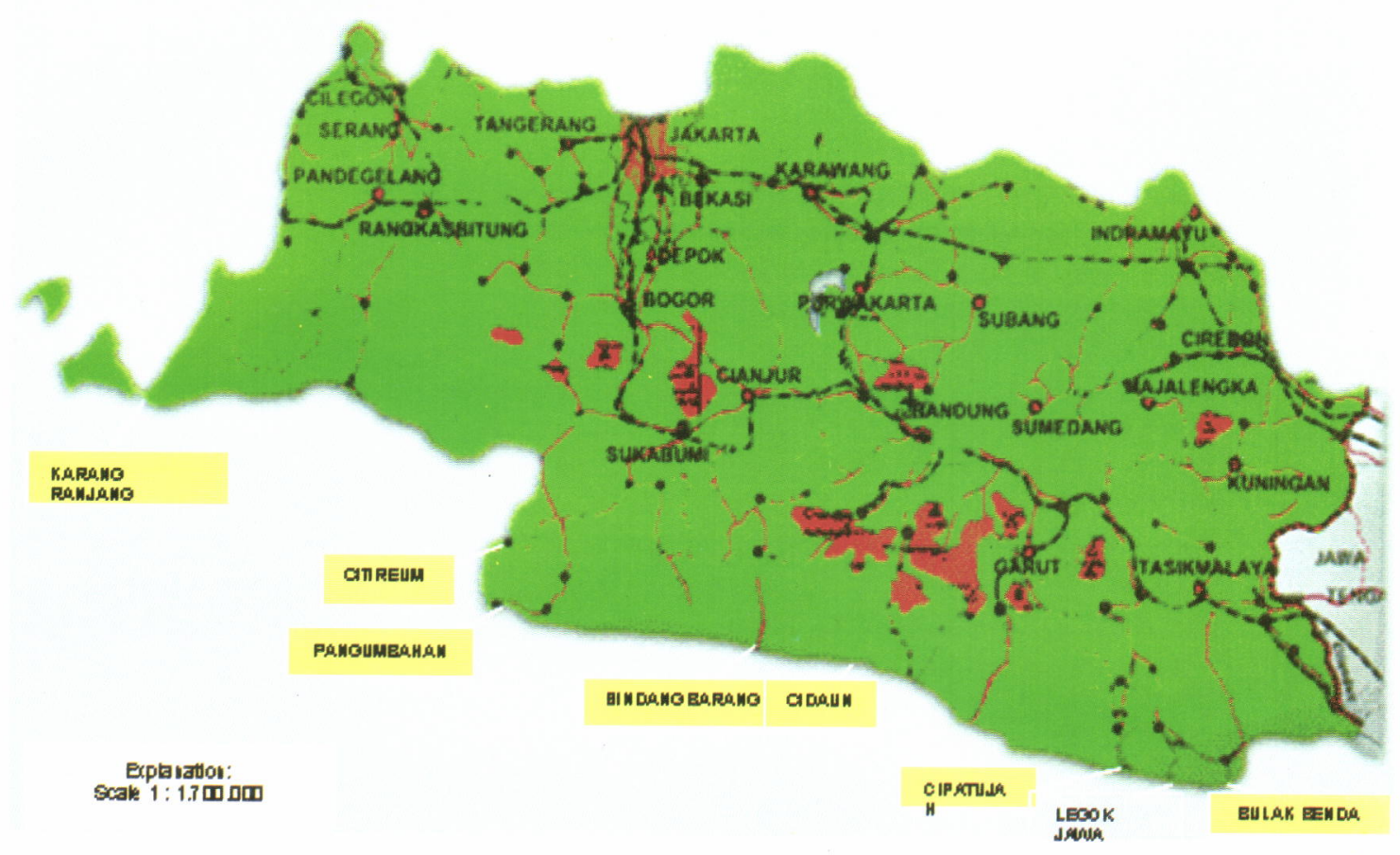

Figure 1. The site of research on sea turtle nesting habitat in West Java Province. 
Present Status of Nesting Habitat of Green Turtlen ..... in West Java-Indonesia (Krismono, A.S.N., et al.)

Table 1. Several parameters observed during sea turtle field survey in West Java in 2008

\begin{tabular}{|c|c|c|c|}
\hline No. & Parameters observed & Unity & Tools and Methodology \\
\hline & $\begin{array}{l}\text { Biology and Ecology of the } \\
\text { Beach }\end{array}$ & & \\
\hline 1. & Beach width & m & Roll meter, direct measurement \\
\hline 2. & Beach elevation & $\operatorname{Deg}\left({ }^{\circ}\right)$ & Roll meter, polyethylene rope, role, direct measurement \\
\hline 3. & Sand humidity & $\%$ & Soil tester, direct measurement \\
\hline \multirow[t]{2}{*}{4.} & Sand $\mathrm{pH}$ & unit & Soil tester, direct measurement \\
\hline & Substrate Composition & & \\
\hline 5. & Sand size & $\mathrm{mm}$ & Shave shaker, analysis in laboratorium \\
\hline 6. & Metal mineral content & $\%$ & Magnetic tool and digital balance, analysis in laboratorium \\
\hline 7. & Sand form & qualitative & Microscope, analysis in laboratorium \\
\hline 8. & Organic content & $\%$ & Oven, digital balance, $\mathrm{HCl}$, disk, analysis in laboratorium \\
\hline \multirow[t]{2}{*}{9.} & Beach vegetation & qualitative & Visual, identification book, direct measurement \\
\hline & Biology of Sea Turtle & & \\
\hline 10. & Sea turtle species & Species & Visual, sea turtle guideline book, direct measurement \\
\hline 11. & Morphometrie & $\mathrm{cm}$ & Role and CCL method, direct measurement \\
\hline 12. & $\begin{array}{l}\text { Number of nesters, number of } \\
\text { eggs, and hutched level }\end{array}$ & numeric & $\begin{array}{l}\text { Visual, manual, interview, data collecting, direct } \\
\text { measurement }\end{array}$ \\
\hline 13. & Nester behaviour & qualitative & Visual and camera, direct observation \\
\hline 14. & Tagging & & Aplicator dan inconnel, direct measurement \\
\hline \multirow[t]{2}{*}{15.} & Eggs exploitation level & $\%$ & Secondary data \\
\hline & Social-Economic & & \\
\hline 16. & Social-Economic and Organization & qualitative & Quesionaire, interview \\
\hline 17. & $\begin{array}{l}\text { Community Perception and } \\
\text { Participative Role }\end{array}$ & qualitative & Quesionaire, interview \\
\hline
\end{tabular}

by Nuitja (1992). This indicates that green turtle landed during this study were older than green turtle nesters observed by Nuitja (1992).

During field survey in eight nesting sites, the succsess of direct observation was only at the Citirem and Pangumbahan Beaches. About 78 individuals of green turtle were seen to land at those beaches. Only 38 individuals (45\%) laid the eggs with variation $0-120$ eggs and 40 individuals (55\%) were doing false crawl (unnesting). The false crawl on turtle may be caused by some factors, such as: light pertubation, no vaporable sand conditon, less vegetation, relatively high beach elevation, and turtle orientation for searching the appropriate nesting habitat (Miller, 1997).

The beach elevation may influence sea turtle landing. Sea turtle searches and prefer the part of beach with low elevation less than $30^{\circ}$ as reported by Nuitja (1992). At the beach with low elevation sea turtle may go up easyly to the beach.

\section{Activity on hatchery}

Semi natural hatchery in Pangumbahan Beach had been done as part of the sea turtle management and conservation by the private company for several times ago. During these times (exemple for data in 2007) the number of incubated eggs were $<50 \%$, while after the change of the Pangumbahan Beach management to the local goverment, the number of incubated eggs were $100 \%$ as presented in detail in Table 4.

\section{Utilization and Conservation of Sea Turtle Eggs}

Among eight nesting sites observed in West Java, there is only Pangumbahan Beach where green turtle is found to nest frequently. This site had been managed by a private company during more than 25 years until August 2008. After that, the site is managed by the local government under the Marine and Fisheries Agency of Sukabumi District. During the period under private company management, about $30 \%$ of the eggs produced were exploited for the operational budget to maintain the rockery. Under goverment management, there is no more exploitation of turtle eggs. All eggs produced are incubated in semi natural hatchery to avoid the loss of the eggs due to the predator and poacher. This effort is expected to enhance the hatchling production. Actually, the hatching rate of the eggs is nearly 90100\% (Table 5). 


\begin{tabular}{|c|c|c|}
\hline Beach & $\begin{array}{c}\text { Geographical } \\
\text { Position }\end{array}$ & Nesting habitat characteristic \\
\hline $\begin{array}{l}\text { Karang Ranjang } \\
\text { (Ujung Kulon NT) }\end{array}$ & $\begin{array}{l}06^{\circ} 50^{\prime} 05.29^{\prime \prime} \mathrm{S}, 105^{\circ} \\
27^{\prime} 03.08^{\prime \prime} \mathrm{E}\end{array}$ & $\begin{array}{l}\text { Site: Located at main zone of Ujung Kulon National Park. The beach is } \\
\text { quite far from habitation with difficult acssess and relatively ideal for } \\
\text { nesting habitat of sea turtle. Before } 2000 \text {, there were green turtle and } \\
\text { leatherback, landed in this beach. } \\
\text { Width: } 23.4 \mathrm{~m} \\
\text { Elevation: } 3.66^{\circ} \\
\text { Sand humidity and pH: } \pm 30.2^{\circ} \mathrm{C} \text { and } 6.5 \text { units } \\
\text { Sand size and content: }<500-250 \mathrm{~mm}\end{array}$ \\
\hline $\begin{array}{l}\text { Citireum, } \\
\text { Sukabumi }\end{array}$ & $\begin{array}{l}7^{\circ} 13^{\prime} 29.08^{\prime \prime} \mathrm{S}, 106^{\circ} \\
53^{\prime} 43.05^{\prime \prime} \mathrm{E}\end{array}$ & $\begin{array}{l}\text { Site: managed by the institute for Natural Resources Conservation, The } \\
\text { Ministry of Forestry (BKSDA). The beach is quite far from habitation with } \\
\text { difficult access and relatively ideal for nesting habitat of sea turtle. It is } \\
\text { noted that it is just only green turtle, landed in this beach. } \\
\text { Width: } 30.39 \mathrm{~m} \\
\text { Elevation: } 2.98^{\circ} \\
\text { Sand humidity and pH: } \pm 310 \mathrm{C} \text { and } 7 \text { units } \\
\text { Sand size and content: }<250-150 \mathrm{~mm}\end{array}$ \\
\hline $\begin{array}{l}\text { Pangumbahan, } \\
\text { Sukabumi }\end{array}$ & $\begin{array}{l}07^{\circ} 19^{\prime} 52.95^{\prime \prime} \mathrm{S} \\
108^{\circ} 23^{\prime} 47.19^{\prime \prime} \mathrm{E}\end{array}$ & $\begin{array}{l}\text { Site: historically managed by a private company and now the beach is } \\
\text { managed by Fisheries Agency. The beach is the best nesting habitat for } \\
\text { sea turtle. There is good accessibility to reach the beach, that it is some } \\
\text { times might be vulnerable for nesting site without well management. } \\
\text { Dominant nester is green turtle, but in the long time ago some hawksbill } \\
\text { had been landed in the beach. } \\
\text { Wicth: } 3-4 \mathrm{~m} \\
\text { Elevation: } 3.1^{\circ} \\
\text { Sand humidity and } \mathrm{pH}: 29.6^{\circ} \mathrm{C} \text { and } 6.5 \text { units } \\
\text { Sand size and content: }<250-150 \mathrm{~mm}\end{array}$ \\
\hline $\begin{array}{l}\text { Sindang Barang, } \\
\text { Cianjur }\end{array}$ & $\begin{array}{c}7^{\circ} 27^{\prime} 47.11^{\prime \prime} \mathrm{S}, 107^{\circ} \\
\text { O9' } 21.85^{\prime \prime} \mathrm{E}\end{array}$ & $\begin{array}{l}\text { Site: quite ideal for nesting habitat, but no body or institution are aware } \\
\text { about the site. Recently, there are aimost no more turtles landed in the } \\
\text { beach. Before } 1990 \text {, there were about } 4-5 \text { nesters of green turtles } \\
\text { coming up to the beach. } \\
\text { Width: } 72.47 \mathrm{~m} \\
\text { Elevation: } 1.67^{\circ} \\
\text { Sand humidity and pH: } 38.5 \circ \mathrm{C} \text { and } 7 \text { units } \\
\text { Sand size and content: }<250-150 \mathrm{~mm}\end{array}$ \\
\hline Cidaun, Cianjur & $\begin{array}{l}7^{\circ} 29^{\prime} 52.99^{\prime \prime} \mathrm{S}, 107^{\circ} \\
23^{\prime} 00.77^{\prime \prime} \mathrm{E}\end{array}$ & $\begin{array}{l}\text { Site: historically the beach had been known as nesting habitat. The } \\
\text { condition was changed due to the beach utilization for tourism, fishing, } \\
\text { and transportation. It seems that the waters around the site still serve as } \\
\text { feeding and nursery ground for sea turtles. } \\
\text { Width: } 29.48 \mathrm{~m} \\
\text { Elevation: } 3.48^{\circ} \\
\text { Sand humidity and } \mathrm{pH}: 29.67^{\circ} \mathrm{C} \text { and } 6 \text { units } \\
\text { Sand size and content: }<250-150 \mathrm{~mm}\end{array}$ \\
\hline $\begin{array}{l}\text { Cipatujah, Tasik } \\
\text { Malaya }\end{array}$ & $\begin{array}{l}07^{\circ} 46^{\prime} 02.07^{\prime \prime S} \\
108^{\circ} 04^{\prime} 23.7^{\prime \prime} \mathrm{E}\end{array}$ & $\begin{array}{l}\text { Site: the beach is one of the sites managed by the Institute for Natural } \\
\text { Resources Conservation, The Ministry of Forestry (BKSDA). In West } \\
\text { Java Province. The beach is located nearby the communal road, giving a } \\
\text { very good access to the site. Recently, there is less and less turtles } \\
\text { landed in the beach. This may be due to the some activities in the waters } \\
\text { around the site, such transportation and fishing. The waters are still } \\
\text { visited by sea turtles for feeding and swimming. } \\
\text { Wicth: } 27.40 \mathrm{~m} \\
\text { Elevation: } 12.66^{\circ} \\
\text { Sand humidity and pH: } 26.75 \circ \mathrm{C} \text { and } 7 \text { units } \\
\text { Sand size and content: }<500-250 \mathrm{~mm}\end{array}$ \\
\hline
\end{tabular}


Table 2 .

Continue

\begin{tabular}{|c|c|c|}
\hline Beach & $\begin{array}{c}\text { Geographical } \\
\text { Position }\end{array}$ & Nesting habitat characteristic \\
\hline $\begin{array}{l}\text { Legok Jawa, } \\
\text { Ciamis }\end{array}$ & $\begin{array}{l}07^{\circ} 48^{\prime} 37.2 " \mathrm{~S} \\
108^{\circ} 27^{\prime} 21.0^{\prime \prime} \mathrm{E}\end{array}$ & $\begin{array}{l}\text { Site: The beach is quite ideal for nesting habitat. However, there is no } \\
\text { management activity, causing the degradation of beach and changing the } \\
\text { function of the beach, especially for development of fishery and } \\
\text { settlement. However, some people are aware about the sea turtle } \\
\text { conservation with their activity to watch sea turtles and do natural } \\
\text { hatchery and restocking of hatchlings. } \\
\text { Width: } 32.00 \mathrm{~m} \\
\text { Elevation: } 11.77^{\circ} \\
\text { Sand humidity and } \mathrm{pH}: 34.1^{\circ} \mathrm{C} \text { and } 7 \text { units } \\
\text { Sand size and content: }<500-250 \mathrm{~mm}\end{array}$ \\
\hline $\begin{array}{l}\text { Bulak Benda, } \\
\text { Ciamis }\end{array}$ & $\begin{array}{l}07^{\circ} 46^{\prime} 53.3^{\prime \prime S} \\
108^{\circ} 30^{\prime} 05.4^{\prime \prime E}\end{array}$ & $\begin{array}{l}\text { Site: geographically the beach is near by Legok Jawa beach. The beach } \\
\text { was much touched by recent tsunami event in } 2004 \text {. In general, the } \\
\text { beach is not match for nesting habitat. } \\
\text { Widht: } 28.46 \mathrm{~m} \\
\text { Elevation: } 7.08^{\circ} \\
\text { Sand humidity and } \mathrm{pH}: 34^{\circ} \mathrm{C} \text { and } 6.5 \text { units } \\
\text { Sand size and content: }<500-250 \mathrm{~mm}\end{array}$ \\
\hline
\end{tabular}

\begin{tabular}{|c|c|c|c|c|c|c|c|c|}
\hline \multirow{2}{*}{ Vegetation species } & \multicolumn{8}{|c|}{ Nesting areas } \\
\hline & KRJG & CITI & PANG & CIUÁ & SINB & CIPA & LGKJ & BLKB \\
\hline Pandan laut (Pandanus tectorius) & vvv & vvv & vvV & vVv & VVV & vVV & vVv & \\
\hline Waru laut (Hibiscus tiliaceus) & & & vVv & & & vV & vV & \\
\hline Nyamplung (Calophyllum inophyllum) & & $v$ & & & & & $v$ & v \\
\hline Jampang pait (Paspalum conjugatum) & & & & & & & v & v \\
\hline Bogem (Soneratia sp.) & & v & $v$ & & & $v$ & $v$ & \\
\hline Rumput kekawatan (Cynodon dactylon) & & & & & & v & & \\
\hline Bebakoan (Scaevola tacada) & $v$ & v & vv & vv & & & & \\
\hline Acanthaceae & & & & & & & & $v$ \\
\hline Ketapang (Terminalia catappa) & $v$ & $v$ & $v$ & $\checkmark$ & $v$ & $v$ & $v$ & $v$ \\
\hline rumput angin (Spinifex littoralis) & $v$ & & & & & & $v$ & \\
\hline Butun (Baringtonia asitica) & v & v & v & $v$ & v & $v$ & $v$ & \\
\hline Kelapa (Cocos nucifera) & & & & & & $v$ & $v$ & $v$ \\
\hline $\begin{array}{l}\text { Kangkung laut (Ipomea pesc Sindang } \\
\text { Barange) }\end{array}$ & vv & vV & vV & vV & vV & vv & vv & vV \\
\hline
\end{tabular}

Notes: vvv: dense; vv: moderate; v: rare; KRJG: Karang Ranjang; CITI:Citireum; PANG: Pangumbahan; CIDA: Cidaun; SINB: Sindang Barang; CIPA: Cipatujah; LGKJ:Legok Jawa; BLKB: Bulak Benda 
Table 4. Variation of the number of produced eggs and its percentage of incubated eggs at Pangumbahan Beach in 2007-2008

\begin{tabular}{|c|c|c|c|c|c|c|c|}
\hline Year & Month & $\begin{array}{l}\text { Number of } \\
\text { produced eggs }\end{array}$ & $\begin{array}{l}\text { Percentage of } \\
\text { incubated eggs }\end{array}$ & Year & Month & $\begin{array}{l}\text { Number of } \\
\text { produced eggs }\end{array}$ & $\begin{array}{l}\text { Percentage of } \\
\text { incubated eggs }\end{array}$ \\
\hline \multirow[t]{12}{*}{2007} & Jan & 9,558 & - & \multirow[t]{12}{*}{2008} & Jan & 2,634 & 47.68 \\
\hline & Feb & 4,227 & - & & Feb & 2,162 & 48.56 \\
\hline & Mar & 3,868 & - & & Mar & 2,698 & 97.25 \\
\hline & Apr & 2,944 & - & & Apr & 2,793 & 100 \\
\hline & May & 4,225 & 50.01 & & May & 2,929 & 100 \\
\hline & Jun & 5,832 & 50.00 & & Jun & 2,710 & 100 \\
\hline & Jul & 4,509 & 50.01 & & Jul & 2,299 & 100 \\
\hline & Aug & 3,056 & 50.00 & & Aug & 20,412 & 100 \\
\hline & Sept & 4,409 & 50.01 & & Sept & 37,785 & 100 \\
\hline & Oct & 6,170 & 50.00 & & & & \\
\hline & Nov & 8,295 & 50.0 & & & & \\
\hline & Dec & 6,530 & 50.00 & & & & \\
\hline
\end{tabular}

Sources: Marine Affairs and Fisheries Service of Sukabumi District (2008)

Table 5. Number of green turtle eggs hatched at Pangumbahan Beach in 2008

\begin{tabular}{|c|c|c|c|c|c|c|c|}
\hline \multirow{2}{*}{ Month } & \multicolumn{2}{|r|}{ Number } & \multirow{2}{*}{$\begin{array}{l}\text { Hatched } \\
\text { eggs }(\%)\end{array}$} & \multirow{2}{*}{ Month } & \multicolumn{2}{|c|}{ Number } & \multirow{2}{*}{$\begin{array}{l}\text { Hatched } \\
\text { eggs }(\%)\end{array}$} \\
\hline & Eggs & Hatchling (ind.) & & & Eggs & Hatchling (ind.) & \\
\hline March & 2,806 & 2,724 & 97 & July & 2,404 & 2,404 & 100 \\
\hline April & 2,693 & 2,573 & 95 & August & 20,392 & 20,392 & 100 \\
\hline May & 2,929 & 2,929 & 100 & September & 37,747 & 37,747 & 100 \\
\hline June & 2,710 & 2,710 & 100 & & & & \\
\hline
\end{tabular}

Sources: Anonymous (2008)

At Citireum and Cipatujah nesting habitats, the number of sea turtle eggs was utilized about $10-50 \%$ by the people for food. In Cipatujah, some people are aware on sea turtle conservation. About $50 \%$ of total eggs taken by the people are brought to the the rockery managed under the Institute for Natural Resources Conservation (BKSDA) for incubating. Based on information from workers, the number of sea turtle eggs was hatched about $70-80 \%$. This condition is due to the media condition, that is qualitatively worse (the sand utilized for media is not changed frequently and a lot of hunts around the eggs).

The same case apprears at Legok Jawa nesting habitat. A part of community who found and collected eggs gave in volunteer to the group of environmental awareness people. The group gave some money to the people as award. Different to the Cidaun and Sindang Barang nesting habitat which are formally under the Institute for Natural Resources Conservation (BKSDA), however there is not any management activities. This causes some eggs and also sea turtle inviduals taken by local people as similarly happened at Bulak Benda.

\section{Socio-Economic and Cultural Condition}

Most of the people living around the nesting areas both at the sea turtle conservarion zone and non conservation zone, work as agriculturist, fishermen, commercant, labour, and government officer. Labour and fishermen are still prospective job for the local people, even though they are still poor. This condition may stimulate them to exploite eggs and sea turtle in the nesting area or in around coastal waters. This direct take is usually done by the people during bad condition for fishing.

In general the people living at around the research sites has low level education (elementary school), and very few reached an university level. This conditon may influence their scientific level dan innovation capacity.

Sea turtles may be used in cultural ceremony. The people, especially from chinese ethnic do marriage ceremony prior releasing some hatchlings to the sea. The hatchlings were usualy bought at Pangumbahan rockery. This cultural activity might contribute a 
positive impact to the management measure in sea turles enhancement.

\section{Institution and Management Activity}

The most management effort of nesting habitats in the research locations is done by the Institute for Natural Resources Conservation (BKSDA) as presented in Table 6. However, the only one nesting beach managed by private company seems be the best nesting area in West Java, that is Pangumbahan Beach. In fact, the BKSDA does not concentrate to manage all nesting areas of their autorithy, such as Sidang Barang, Cidaun and Karang Ranjang Beaches. The main taks of BKSDA is to manage forestry resources concervation. Just only one institution, namely Suaka Margasatwa Laut Sidang KertaCipatujah that concentrates in managing nesting habitat of sea turtle, that is Cipatujah Nesting Area. The conservation activity includes protection and maintenance of hatchery, egg collecting, incubation, hatchling, and restocking. Some problems encountered during implementation of conservation activity are the beach used as transportation track and fishing activities using some kind of nets.

\section{Hatchling Restocking}

During eight years (2001-2008) the private company as a management authority at Pangumbahan Beach had collected about $6.26 \times 10^{5}$ eggs and produced hatchlings ready to release of about $1.36 \times 10^{5}$ individuals $(21.68 \%)$ of total eggs collected (Table 7). By the reason to support the operasional of sea turtle conservation, about $70 \%$ of total eggs collected were sold by the company in the local markets aroud West Java Province.

At Cipatujah Beach under the Institute for Natural Resources Conservation (BKSDA West Java, Suaka Margasatwa Laut Sindangkerta), sea turtle restocking has been done since 1990 . There are no continued record data on landed sea turtles and produced eggs. In 2002 and 2003, the number of landed sea turtles was recorded about 60 and 84 individuals, respectively. The number decreased in 2006 and 2007 when the landed sea turtles were 54 and 41 individuals, respectively. The number of produced eggs in 2007 was about 4,442 eggs, resulting hatchlings of total about 3,500 individuals released monthly to the sea (Table 8).

At Legok Jawa Beach the hatchling restocking activity has been done since 2006 by volunteer people who established a Community Group on Environmental Awareness. However, their activity is not intensiv because of the limited budget and equipment. Usually this group must buy eggs collected by local people. The recent record of 2008 the group succeeded to incubate about 260 eggs. All hatchlings produced from semi natural hatchery were released directly to the sea. Although the hatchlings produced are still in small quantity, this initiative is positive effort in turtle conservation development in West Java region. Therefore, the Group needs a financial support from a donor or government in achieving their participation of the sea turtle conservation.

At Citirem Beach, the hatchlings restocking activity is done infrequently and in small scale, especially during the visits of groups of the students. This condition is due to other activity of BKSDA which has main duty to guard the forestry conservation. There is no continued record on landed sea turtles and produced eggs. During observation, there were about 7 green turtles landed in the beach with the number of eggs recorded of $97-137$ eggs/female. From this quantity of eggs incubated, it resulted about 80-200 individuals of hatchling per month. The hatchlings were all released directly to the sea.

\section{Perception and Participation of Community in Sea Turtle Conservation Effort}

In general the participation level of community on sea turtie conservation is at the level of understanding about conservation area. Some people at several locations have relatively high level of participation, such

Table 6. Management status in the nesting areas of West Java.

\begin{tabular}{cll}
\hline No. & \multicolumn{1}{c}{ Research Location } & \multicolumn{1}{c}{ Management Status } \\
\hline 1 & Karang Ranjang Beach & BKSDA West Java, Ujung Kulon National Park \\
2 & Citirem Beach & BKSDA West Java, Suaka Margasatwa Cikepuh \\
3 & Pangumbahan Beach & Daya Abadi Company (private company) \\
4 & Cidaun Beach & BKSDA West Java, Cagar Alam Gunung Simpang \\
5 & Sindang Barang Beach & BKSDA West Java, Cagar Alam Bojong Larang Jayanti \\
6 & Cipatujah Beach & BKSDA West Java, Suaka Margasatwa Laut Sindangkerta \\
7 & Legok Jawa Beach & Community Group for Marine Protection Legok Jawa \\
8 & Bulak Benda Beach & No management existing \\
\hline
\end{tabular}


Table 7. Number of eggs collection and produced hatchling at Pangumbahan Beach in 2001-2008.

\begin{tabular}{cccc}
\hline Year & Number of Eggs & $\begin{array}{c}\text { Number of Produced Hatchling } \\
\text { (Individuals) }\end{array}$ & Percentage \\
\hline 2001 & 96,401 & 17,500 & 18.15 \\
2002 & 100,822 & 6,700 & 6.64 \\
2003 & 88,859 & 21,100 & 23.74 \\
2004 & 99,199 & 29,575 & 29.81 \\
2005 & 100,789 & 13,950 & 13.84 \\
2007 & 63,623 & 30,360 & 47.72 \\
2008 & 76,422 & 16,568 & 21.68 \\
\hline Total & 626,115 & 135,753 & 21.68 \\
\hline
\end{tabular}

Table 8. Fluctuation of produced eggs and hatchlings at Cipatujah Beach in 2007

\begin{tabular}{lcclcc}
\hline Month & $\begin{array}{c}\text { Number of } \\
\text { eggs }\end{array}$ & $\begin{array}{c}\text { Number of hatchlings } \\
\text { (individuals) }\end{array}$ & Month & $\begin{array}{c}\text { Number of } \\
\text { eggs }\end{array}$ & $\begin{array}{c}\text { Number of hatchlings } \\
\text { (individuals) }\end{array}$ \\
\hline January & - & 160 & Augusts & 448 & 372 \\
February & 176 & Nd & September & 355 & 767 \\
March & 227 & nd & October & 200 & 419 \\
April & 381 & 163 & November & 267 & 300 \\
May & 626 & 203 & December & 434 & 388 \\
June & 470 & 338 & Total & 4,442 & 3,489 \\
July & 858 & 579 & & & \\
\hline
\end{tabular}

as at Pangumbahan Beach, Citirem Beach, Cipatujah Beach, and Legok Jawa Beach. The people participation are collecting sea turtle eggs and returning its to the conservation management authority. At Legok Jawa Beach people who found sea turtle eggs in the beach return or sell part of the eggs to the Community Group on Environmental Awarness. The Group then incubated the eggs in the beach and the hatchling produced are released directly to the sea. This volunteer group expect deeply to the government for disseminating and improving the understanding of the law concerning the marine resources conservation. While at Bulak Benda, Cidaun and Sindang Barang the participation level of local community in the conservation action is low. In those locations, the direct take of sea turtle eggs and individual is still done by the people.

\section{CONCLUSIONS}

1. Based on ecology indentification of eight beaches observed in West Java Province, all beaches seem be ideal to support the green turtle conservation. Among eight nesting beaches observed, Pangumbahan Beach is the best nesting habitat in West Java Province, that had been well managed by a private company for several years ago and actually is continued by Marine and
Fisheries Service of Sukabumi District. Somes of nesting habitat are managed by the Institute for Natural Resouces Conservation (BKSDA), including Citirem Beach, Cidaun Beach, Sindang Barang Beach, with eggs produced and hatchlings released to the sea were less compared to produced and released in Pangumbahan Beach. Legok Jawa Beach was determined as a prospective nesting habitat of sea turtle where the participation of volunteer people in sea turtle conservation might be positive way to develop Legok Jawa Beach as sea turtle conservaton zone.

2. Green turtle is dominant nester in West Java Province. An average size of curve carapace length (CCL) of the nesters was $102.8 \mathrm{~cm}$ with a number of eggs laid varying from $90-120$ eggs per female. The nesting season occoured a long of year with the peak in August-September.

3. It is suggested that further research to cover the other potential or prospective nesting habitats of sea turtles in West Java, in order to revitalize the nesting beach management in the region is needed. Indeed, the local goverment should support to the volunteer people who have intiative in sea turtle conservation. 


\section{ACKNOWLEDGMENTS}

This paper is a contribution of the research activity with title "The Evaluation of Sea Turtles Evaluation in Southern Coast of Java (West Java and Banten Provinces)", under national budget of 2008 fiscal year. The authors wish to thank to the Marine and Fisheries Service of Sukabumi District (Dinas Kelautan dan Perikanan Kabupaten Sukabumi) and the Institute for Natural Resouces Conservation (BKSDA) at Cipatujah who provided the data and information on sea turles landing. Many thanks are dedicated to the Editors of this jurnal.

\section{REFERENCES}

Abdullah, S. \& M. Ismail. 2004. Temperature dependent sex determination and hatching performance of green turtles (Chelonia mydas) at Chendor Rookery on the east coast of Peninsular Malaysia. Proceedings of the International Symposium on SEASTAR2000 and Bio-logging Science. Bangkok. 11-15.

Adnyana, W., L. Pet Soede, G. Gearheart, \& M. Halim. 2008. Status of green turtle (Chelonia mydas) nesting and foraging populations of Berau, East Kalimantan, Indonesia, including results from tagging and telemetry. Indian Ocean Turtle Newsletter. 7: 1-10.

Anonymous. 2008 (In Indonesian). Data on the number of sea turtle nesting in Pangumbahan Beach. Marine and Fisheries Service of Sukabumi District. (Unpublished).
Dermawan, A. 1997 (In Indonesian). Guideline of Sea Turtle and its Habitat Conservation. Directorate of Conservation and National Park. Directorate General of Marine. Coastal and Small Islands. Jakarta.

Dharmadi \& N. N. Wiadnyana. 2008 (In Indonesian). Habitat condition and its relation to the number of green turtle (Chelonia mydas) nesting in Derawan Island, Berau-East Kalimantan. Jurnal Penelitian Perikanan Indonesia. 14. 2: 195-204.

Miller, J. D. 1997. Reproduction in Sea Turtle. In P. L. Lutz \& J. A. Musick (Eds). The Biology of Sea Turtle. 51-81.

Nuintja, I. N. 1992. (in Indonesian). Biology and Ecology of Sea Turtle Conservation. Bogor Agricultural Institut. Bogor.

Nursahid, R. 2003. (In Indonesian). Sea Turtle Population in Indonesia. endangered. http;//www. Tempointeraktif.com., 25 June 2003.

Yasuda, T., K. Kongkiat, K. Winai, \& Nobuaki. 2005 Seasonal nesting of green turtles at Huyong Island. Thailand. Procedings of the 2 International symposium on SEASTAR 2000 and Asean Biologging Science (The 6 SEASTAR 2000 workshop). Bangkok. 51-54.

Yusuf, A. 2000. (In Indonesian). To know Sea Turtle Yayasan Alam Lestari. Jakarta. 
